Article

\title{
Determinants of Energy Saving: Evidence from a Vocational School in Greece
}

\author{
Daiva Dumciuviene * ${ }^{\mathbb{D}}$, Akvile Cibinskiene $\mathbb{D}$ and Meda Andrijauskiene \\ School of Economics and Business, Kaunas University of Technology, LT-44239 Kaunas, Lithuania; \\ akvile.cibinskiene@ktu.lt (A.C.); meda.andrijauskiene@ktu.lt (M.A.) \\ * Correspondence: daiva.dumciuviene@ktu.lt
}

Received: 13 August 2019; Accepted: 23 September 2019; Published: 24 September 2019

\begin{abstract}
For this paper, the authors theoretically analyzed the determinants of energy saving and sustainable energy consumption in schools. Much research exists on energy-saving behavior in residential buildings. However, there is a lack of focus on public buildings and schools. A systematic literature review was conducted in order to construct the theoretical background for the research of school buildings, which are substantially less investigated. The determinants of sustainable energy use in schools were grouped together into three groups: (i) psychological and social, (ii) sociodemographic and economic, and (iii) contextual. The influence of these determinants on energy consumption was investigated empirically by conducting a questionnaire survey in a vocational school in Greece. The results reveal that the intention to save a substantial amount of energy in a vocational school in Greece is greater when students feel morally obliged to consider the environment and nature, believe that it is in their power to avoid unnecessary power consumption, and are positively influenced by teachers, classmates, and other important people in their lives.
\end{abstract}

Keywords: sustainable energy consumption; energy saving; energy-saving behavior; determinants; schools

\section{Introduction}

Environmental changes, such as global warming, climate change, and pollution, are growing in importance among policy makers, environmental practitioners, and researchers. In addition to concern about increasing economic costs and the environmental effect of energy consumption, research recognizes that buildings and their occupants are resources that could be used to achieve energy-saving targets. Many scientific papers ([1-4]) focus on the improvement of technical solutions in terms of energy efficiency and, therefore, there is a lack of analysis concerning the behavioral aspects of energy saving. Pisello et al. ([5], p. 485) mention that "in educational and research buildings occupants spend most of their daytime doing sedentary intellectual activities that require specific indoor comfort conditions". They also note that the combination of technical solutions and behavior may lead to better building energy efficiency. Thus, researching human behavior patterns has become essential in solving global environmental problems. Some scientists underline the importance of energy-saving behavior in terms of sustainable energy consumption in buildings ([5,6]). Issues and behavior related to energy saving in residential buildings have been widely studied. However, the results of previous studies that focus on the residential sector cannot be used for educational buildings because of different intentions to save energy and behaviors. The main difference between residents in residential buildings and occupants in schools is the accessibility to energy bills and their payment.

A total of 30 percent of final energy consumption of electricity was used by computing in offices in the European service sector between 1990 and 2009 [7]. Energy consumption in buildings accounts for up to 40 percent of the global total [8], of which 55 percent of the energy is used for heating, 
ventilation, and air conditioning in offices, whereas 17 percent is used for lighting [6]. These numbers underline the importance of possibilities to save energy not only in the residential sector, but in offices, public buildings, and the educational sector.

Increased results regarding energy saving may be achieved by deploying new technologies in school buildings. This method of energy saving requires an initial investment. Another way to achieve energy-saving goals in schools may be through the occupants' behavior, which does not require a large investment. A study of a successful energy education project in Greece revealed that "energy squandering could be better remedied by education and legislation rather than advanced technological solutions" ([9], p. 3227). Energy-saving behavior may be learned not only from teachers, but from other students as well [10]. The best time for the formation of energy awareness and values is childhood. Therefore, the energy-saving behavior training in schools is of great importance. In order to discover the measures having the biggest impact on energy-saving behavior in schools, researchers should identify and study the determinants of sustainable energy consumption in schools. Energy-saving behavior within the educational sector provides an important opportunity to conserve energy. Energy saving in schools can be achieved by changing the behavior of occupants (students, administrative staff, and teachers). It is important to educate and train students, and to improve their knowledge and skills for the efficient use of energy. The research of Craig and Allen [11] proves that energy literacy at school has a positive impact on energy-saving behavior, which could later be applied in future homes and work places. On the other hand, Kastner and Matthies [12] stress the role of professors and lecturers, who may not only contribute directly to a reduction of energy use but may also affect students' behavior. DeWaters and Powers [13] highlight the importance of energy literacy as an important life skill that could empower today's students as well as the general public. Castleberry et al. [14] and Schelly et al. [10] highlight the energy-saving benefits for schools in terms of cost savings. The latter state that "Energy conservation is important to public schools because of the potential benefits that could be generated for the schools and the surrounding community. For example, schools faced with shortages in funding could realize financial benefits from savings on energy costs" ([14], p. 216). It is important to note that behavioral energy saving is associated with nil or low implementation costs. Although some studies $[15,16]$ found that the decreases in energy consumption due to changed behavior lessened over time, this is understandable because the amounts of energy saved are limited.

While an abundance of research is available for the determinants, strategies, and interventions with respect to household energy consumption, far less is known with respect to energy behavior in public buildings and schools. A systematic literature review was conducted for the substantially less investigated building types (i.e., schools). Based on the results of this literature review, a questionnaire survey was conducted in order to check whether the results were valid. The objective of this paper was to investigate and systematize the determinants of energy consumption behavior in schools, and to check their importance using a Greek school case.

\section{Methods}

This article contains both a systematic literature review and an empirical part based on correlation and regression analysis of the results from the questionnaire survey.

\subsection{Literature Review}

The review was conducted using the systematic literature review methodology defined by Moher et al. [17]. Systematic reviews are a type of literature review that uses systematic methods to collect secondary data, critically appraise research studies, and synthesize findings qualitatively or quantitatively [18]. A systematic literature review identifies, selects, and critically appraises research in order to answer a clearly formulated question [19]. This method allowed us to provide a complete, exhaustive summary of current evidence on sustainable energy consumption determinants 
in schools. The research question was formed using the following set of search terms (based on Dumciuviene et al. [20]):

- Energy consumption ((energy OR electricity) AND ((consumption OR efficiency OR saving OR conservation OR reduction) OR "energy use" OR "electricity use") AND behav*);

- School (school OR classroom OR university OR student* OR teacher*);

- Determinants (predictor ${ }^{*}$ OR determinant* OR factor ${ }^{*}$ OR attitude ${ }^{*}$ OR value ${ }^{*}$ OR knowledge OR belief* OR habit OR norm*);

- Intervention (intervention OR program OR campaign).

ScienceDirect, Elton B. Stephens Company (EBSCO—EconLit, GreenFile), Emerald, WEB of Science, and Scopus were employed as the most reliable sources of research on determinants of energy consumption.

The increasing interest in scientific papers on sustainable energy behavior was observed since 2000. The search results of papers published during 2000-2017 were imported into a spreadsheet and subsequently either included or excluded, based on the title (first round) and abstract (second round). A summary of the selection process, including the main reasons for rejection, is provided in Table 1.

Table 1. Summary of the selection process.

\begin{tabular}{lcc}
\hline & Characteristic & No. of Papers \\
\hline & $\begin{array}{c}\text { Studies found } \\
\text { Accepted }\end{array}$ & 260 \\
31 & Main reasons for rejection & 124 \\
\hline - & & 21 \\
- Residential building studies & 12 \\
- Focus on dormitories in schools or rented apartments (more linked to residential buildings) & 9 \\
- No focus on energy-saving behavior & 39 \\
\hline
\end{tabular}

Source: own elaboration.

Of the 260 search results, 31 were selected for the review (11.9\% acceptance rate). These results prove that efficient energy consumption and energy-saving behavior is still little investigated in educational sector buildings. However, the increasing number of research papers on this topic in recent years (from 1 or 2 papers during 2007-2013, to 8 papers in 2015 and 6 papers in 2016) indicates the growing relevance of this issue. While a majority of rejected papers were widely out of scope, the other main reasons for rejecting papers were that they covered other sectors, or that they considered a scope too broadly by focusing on sustainable behavior in general or structural measures to improve energy saving without considering the occupants of a building.

Authors have categorized "various individual (socio-demographic and psychological) and situational (contextual and structural) factors that may influence household energy consumption and conservation" ([20], p. 2). Having assessed the peculiarities of energy consumption in schools, we adopted the classification of determinants to educational buildings (Figure 1). 


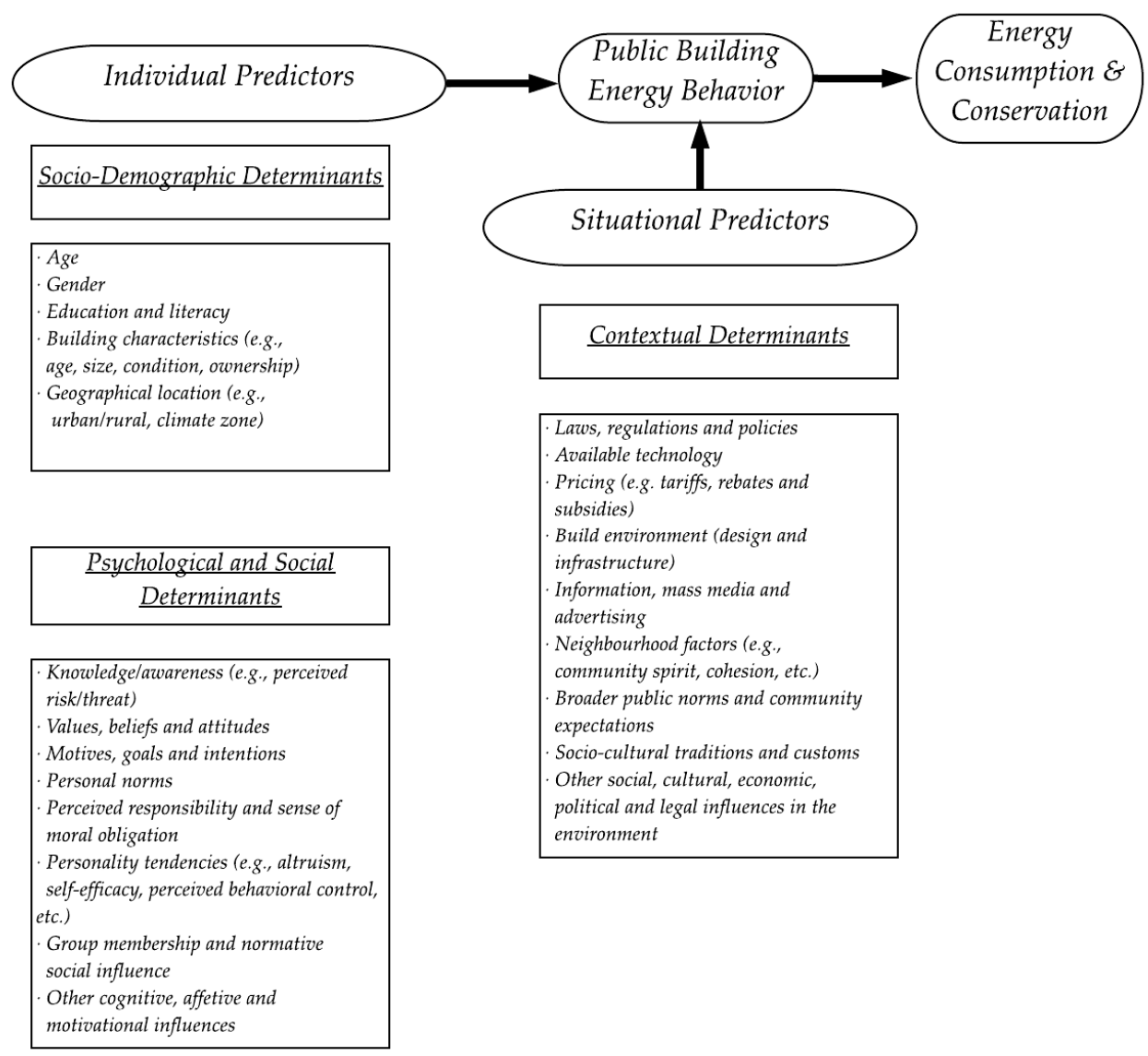

Figure 1. Determinants that may influence energy-saving behavior in schools. Adapted for public buildings under Frederiks et al. [21].

After a detailed analysis of all groups of energy consumption determinants, they were sorted into three groups: psychological and social determinants, sociodemographic and economic determinants, and contextual determinants.

\subsection{Questionnaire Survey}

During the analysis of scientific literature, we discovered that questionnaires $[1,6,8,12,22]$ or mixed methods where questionnaires were later combined with surveys, focus groups, pilot studies, or energy data collection $[1,6,8,12-14,22,23]$ were most often used to evaluate energy savings in schools.

Since behavior-related aspects can have an impact on energy savings, a questionnaire survey was performed as an addition to the measurement of energy consumption in pilot sites of the project "enCOMPASS - Collaborative Recommendations and Adaptive Control for Personalized Energy Saving" (funded by the EU H2020 Programme, grant agreement no. 723059). One of the objectives of the mentioned project was to validate the relative effectiveness of different types of behavioral change interventions for different types of users, in different types of settings, and in different climatic conditions. Hence, an empirical study was conducted in order to find out how attitudes, motivation, knowledge, and awareness (the most important determinants of energy consumption in schools, according to the literature review) affect a student's behavioral intention to save energy. 
The particular sampling frame consisted of 110 students who were studying in a vocational school in Greece during March 2019. The following constructs were selected and composed of multiple items, using Likert scales and semantic differentials:

- Attitudes (1): personal norms (derived from the Norm Activation Model, Schwartz [24]; five items derived from Steg et al. [25]; e.g., "I feel morally obliged to save energy").

- Attitudes (2): perceived behavioral control (three items derived from Thøgersen \& Grønhøj [26]; e.g., "I believe that I'm able to avoid all necessary electricity consumption in my home").

- Motivation: the respondent's motivation to save energy (e.g., to save money; to protect the environment; to feel satisfied).

- Behavioral intention to save energy (three items formulated from the Theory of Planned Behavior, Ajzen [27]; e.g. "I plan to save a substantial amount of energy in the next 3 months").

- Knowledge: self-reported knowledge of energy-saving actions (five items; e.g., "I know how much energy my laptop or computer consumes").

- Awareness: ascription of responsibility (derived from the Norm Activation Model, Schwartz [24]; five items derived from Steg et al. [25]; e.g., "I feel jointly responsible for the exhaustion of energy sources").

Apart from these measures, the following data were collected as covariates for the analyses:

- Basic demographics (e.g. gender, age group, educational level, and study field);

- Subjective norm items to assess the influence of teachers, classmates, and people in respondents' private lives on the intention to save energy, following Lo et al. [28].

Instruments were composed of multiple items, using Likert scales or semantic differentials. The survey sample obtained consisted of $59.09 \%$ female students and $40.91 \%$ male students. Table 2 demonstrates that the largest age group of the sample was 20 or younger $(75.45 \%)$, followed by students between 21 and $30(18.18 \%)$, between 31 and $40(5.45 \%)$, and with one respondent between 41 and 50 years old.

The majority of participants stated that their highest level of education was post-secondary non-college education ( $80 \%)$, whereas smaller numbers of the group had completed upper secondary education $(9.09 \%)$, or bachelor's or equivalent level (8.18\%). Lower secondary education, master's level, or doctoral level were obtained by one person each.

The majority of students were involved in tourism $(27.27 \%)$, health and paramedical studies $(22.73 \%)$, information technology $(20.91 \%)$, and fashion and beauty $(18.18 \%)$ fields of study. Others were studying electrical engineering and automation programs $(8.18 \%)$, applied arts $(1 \%)$, social services $(1 \%)$, and business administration (1\%).

Seven different groups of questions were designed for the survey, namely, personal norms (PN); behavioral intention to save energy (BI); subjective norm items to assess the influence of teachers, classmates, and other important people in a respondent's life (SN); energy-saving motivation (EM); self-reported knowledge of energy-saving actions (EN); ascription of responsibility (AR); and perceived behavioral control (PBC).

First, the statistical analysis generated Spearman's correlations of variables with respect to the respondents' energy-saving behavior, attitudes, habits, motivation and their sociodemographic features, such as age, gender, and education level. Second, the authors of this paper proceeded with a regression analysis in order to model and analyze the relationship between behavioral intention to save a substantial amount of energy in the next three months in a respondent's school (a dependent variable) and five predictors. The predictors were (i) personal norms towards the reduction of energy use; (ii) behavioral control to limit power consumption; (iii) knowledge about energy saving; (iv) responsibility for high energy consumption levels; and (v) influence of teachers, classmates, and other important people in the respondent's private life on the intention to save energy. 
Table 2. Survey demographics and descriptive statistics.

\begin{tabular}{|c|c|c|c|}
\hline & Description & $\begin{array}{c}\text { Number of } \\
\text { Respondents }\end{array}$ & $\begin{array}{l}\text { Percentage of } \\
\text { Respondents }\end{array}$ \\
\hline \multirow{2}{*}{ Gender } & Male & 45 & $40.91 \%$ \\
\hline & Female & 65 & $59.09 \%$ \\
\hline \multirow{4}{*}{ Age } & 20 or younger & 83 & $75.45 \%$ \\
\hline & $21-30$ & 20 & $18.18 \%$ \\
\hline & $31-40$ & 6 & $5.45 \%$ \\
\hline & $41-50$ & 1 & $0.91 \%$ \\
\hline \multirow{6}{*}{ Education level } & Lower secondary education & 1 & $0.91 \%$ \\
\hline & Upper secondary education & 10 & $9.09 \%$ \\
\hline & $\begin{array}{l}\text { Post-secondary non-college education (e.g. } \\
\text { professional training, vocational education) }\end{array}$ & 88 & $80.00 \%$ \\
\hline & Bachelor's or equivalent level & 9 & $8.18 \%$ \\
\hline & Master's or equivalent level & 1 & $0.91 \%$ \\
\hline & Doctoral or equivalent level & 1 & $0.91 \%$ \\
\hline \multirow{8}{*}{ Study field } & Information technology & 23 & $20.91 \%$ \\
\hline & Applied Arts & 1 & $0.91 \%$ \\
\hline & Tourism & 30 & $27.27 \%$ \\
\hline & Health and paramedical studies & 25 & $22.73 \%$ \\
\hline & Social services & 1 & $0.91 \%$ \\
\hline & Business administration & 1 & $0.91 \%$ \\
\hline & Fashion and beauty & 20 & $18.18 \%$ \\
\hline & Electrical engineering and automation & 9 & $8.18 \%$ \\
\hline
\end{tabular}

\section{Energy Consumption Determinants in Schools}

\subsection{Psychological and Social Determinants}

Papers analyzing energy consumption in schools focus on a wide range of determinants, including psychological and social ones. Psychological determinants of energy consumption are traditionally related to human psychology (e.g., knowledge, awareness, beliefs, attitudes, motives, intentions, perceived behavioral control, and personal norms). Social determinants, on the other hand, can facilitate or undermine the intrinsic motivation to save energy. They characterize social norms, organizational culture, and social influence. Table 3 presents the most important groups of the determinants of energy consumption behavior in schools that were identified in the literature review.

Table 3. Psychological and social determinants in schools.

\begin{tabular}{cc}
\hline Determinant & References \\
\hline Attitudes & {$[5,6,15,29-34]$} \\
Awareness & {$[11,16,23,35-37]$} \\
Knowledge & {$[1,13,29,35,38,39]$} \\
Education & {$[11,35,37]$} \\
Perceived behavioral control & {$[30,31]$} \\
User perception & {$[8,34]$} \\
Values & {$[1,15,29,40]$} \\
Personal norms, beliefs, ascription of responsibility & {$[29,40]$} \\
Descriptive norms and intentions & {$[30]$} \\
Motivation for energy saving & {$[12,41]$} \\
Organizational policies and incentives & {$[10,38]$} \\
\hline
\end{tabular}

Source: own elaboration.

Attitudes, including those towards general and workplace energy saving, and peers' personal attitudes, knowledge, and awareness, were the most often analyzed determinants. Only two determinants were clearly defined-perceived behavioral control and situational factors. 
Environmental personal norms and environmental worldviews studied by Scherbaum et al. [22] were not defined, but based on value-belief-norm theory. Energy-related knowledge was not defined in the paper of DeWaters and Powers [13] but was investigated in their study as general knowledge and understanding of students about energy use and saving issues. According to Pisello et al. [5], peers' personal attitudes represent a key variable to be considered while predicting the overall building thermal-energy behavior of university buildings. In the study by Mtutu and Thondhlana [1], personal values and situational factors are defined as the determinants of environmental behavior. Castleberry et al. [14] studied knowledge of energy-saving technologies and practices as a variable that can have an effect on energy saving in school.

Azar and Ansari ([29], p. 569) presented research in which they underlined that significant energy savings can be achieved in buildings via the operation of various building systems by occupants and decision makers. The authors identified that "respondents who reported that their motivation to save energy is mainly driven by instructions from facility management have shown both low motivation/intent and energy saving action levels." Dixon et al. [30] studied community influence, descriptive norms, injunctive norms, perceived behavioral control, attitudes, and intentions. The authors focused on the sense of community, highlighting social ties. User perceptions of energy efficiency in school buildings were investigated and measured by Salleh et al. [8] with the aim of benchmarking energy efficiency.

To sum up, psychological and social determinants were analyzed mainly in higher education institutions. The majority of studies focused on school employees and students, and three papers analyzed the behavior of administrative workers. The remaining studies researched other combinations of target groups (e.g., staff, graduate students, faculty).

\subsection{Sociodemographic and Economic Determinants}

Sociodemographic determinants usually refer to age, gender, education, geographical location, or occupational status, whereas economic determinants are associated with the cost-effectiveness of energy saving. Sociodemographic and economic determinants of energy consumption behavior in schools and their references are presented in Table 4.

Table 4. Sociodemographic and economic determinants in schools.

\begin{tabular}{cc}
\hline Determinant & References \\
\hline Demographic factors & {$[1]$} \\
District population & {$[14]$} \\
Household income & {$[14]$} \\
Funding to overcome barriers to energy saving & {$[14]$} \\
Average property value & {$[14]$} \\
Social recognition & {$[29]$} \\
Learning & {$[42]$} \\
\hline
\end{tabular}

Source: own elaboration.

A total of seven sociodemographic and economic determinants were distinguished from four papers from the systematic literature review. Three papers analyzed higher education institutions and one paper focused on schools in general.

While Börner et al. [42] focused on employees working at a university campus, Azar and Ansari [29], Castleberry et al. [14], and Mtutu and Thondhlana [1] researched students, academics, and administrative staff.

\subsection{Contextual Determinants}

The third group of determinants of energy consumption behavior in schools is contextual determinants (see Table 5). 
Table 5. Contextual determinants in schools.

\begin{tabular}{cc}
\hline Determinant & References \\
\hline Institutional policy & {$[29,32,38,43]$} \\
Physical environment constraints & {$[29]$} \\
Sense of community & {$[30]$} \\
Activity-based & {$[35]$} \\
Energy culture & {$[36]$} \\
Technology upgrades & {$[44]$} \\
Metering consolidation & {$[44]$} \\
Control system changes & {$[44]$} \\
Levels and occupant's intervention & {$[45]$} \\
\hline
\end{tabular}

Source: own elaboration.

Nine papers had a focus on contextual energy-saving behavior determinants. The most analyzed determinant was "Institutional policy", with the remainder studied in one paper each. Only one of the listed determinants was defined in the reviewed papers, namely, Sense of community - "A feeling that members have a belonging, a feeling that members matter to one another and to the group, and a shared faith that members' needs will be met through their commitment to be together (McMillan, Chavis, 1986)", as cited in Dixon et al [30].

Azar and Ansari [29] summarized that "contextual factors, which include the ability of occupants to perform a particular action such as changing thermostat set point temperatures, can partially explain why motivation/intent to save energy did not necessarily translate into actions" (Azar and Ansari [29], p. 571). Serghides et al. [45] paid particular attention to the equipment, stating that the "number of equipment in use turned out to be one of the most important variables, determining energy consumption" (Serghides et al. [45], p. 548), however occupant's intervention on temperature control also affects energy consumption. Lourenço et al. [43] analyzed the need to improve energy use management in schools in addition to the building's design and systems. Tornelli [44] identified that savings could be achieved by monitoring and evaluating school usage profiles, making control adjustments, and then analyzing the effects of recommended changes to equipment settings and operating schedules.

The contextual determinants focused on higher education institutions were investigated in six papers. The same determinants in secondary schools and schools in general were analyzed in one paper each. Two research papers studied all persons associated with the school building. The school staff was the focus of two other papers. In one paper, the researchers focused on graduate students, faculty, and staff. In another study, school staff and students were analyzed, whereas the attention in a further study was focused on students and administrative staff.

Azar and Ansari [29] collected data from students, faculty, researchers, and staff. Serghides et al. [45] collected data from occupants of university buildings, Lourenço et al. [43] selected eight secondary schools for their study, and Tornelli [44] researched schools, looking at existing equipment, new construction designs, and behavioral modifications.

\section{Results of Empirical Research}

The literature review revealed that the most important determinants of energy consumption in schools in terms of their influence on consumption are psychological and social ones. These include attitudes; incentives, intentions, and motivation; knowledge; and awareness. Therefore, an empirical study was conducted in order to find out how differently these determinants affect a student's behavioral intention to save energy.

The exact survey questions and the means of the results are presented in Tables 6-12.

Regarding the personal norms, it can be claimed that students do not feel morally obliged to save energy because the majority picked "Neutral" (4) and "Somewhat agree" (5) as an answer to the questions presented in Table 6. It is worth noting that none chose "Completely agree" (7). 
Table 6. Mean for personal norms (totally disagree (1) to completely agree (7)).

\begin{tabular}{cccc}
\hline Code & Question & Mean & Standard Deviation \\
\hline PN & $\begin{array}{c}\text { Personal norms towards the reduction of } \\
\text { energy use (a composite value) }\end{array}$ & 4.54 & 0.86 \\
\hline PN_1 & I feel morally obliged to save energy. & 4.40 & 1.40 \\
\hline PN_2 & I would feel guilty if I did not reduce my & 3.99 & 1.44 \\
\hline PN_3 & I would feel good if I reduced my energy use. & 4.92 & 0.89 \\
\hline PN_4 & $\begin{array}{c}\text { I feel obliged to bear the environment and } \\
\text { nature in mind in my daily behavior. }\end{array}$ & 4.81 & 0.94 \\
\hline PN_5 & I would be a better person if I saved energy. & 4.62 & 1.17 \\
\hline
\end{tabular}

Students as well are not very likely to form a strong behavioral intention to save energy in their school as the majority picked "Neutral" (4) and "Somewhat agree" (5) as an answer to the questions presented in Table 7. It is again worth noting that none of the respondents answered "Completely agree" (7).

Table 7. Mean for behavioral intention (totally disagree (1) to completely agree (7)).

\begin{tabular}{cccc}
\hline Code & Question & Mean & Standard Deviation \\
\hline BI & $\begin{array}{c}\text { Behavioral intention to save a substantial } \\
\text { amount of energy in the next three months in a } \\
\text { respondent's school (a composite value) }\end{array}$ & 4.43 & 1.31 \\
\hline BI_1 & $\begin{array}{c}\text { I will try to save a substantial amount of energy } \\
\text { in the next three months in my school. }\end{array}$ & 4.36 & 1.34 \\
\hline BI_2 & $\begin{array}{c}\text { I intend to save a substantial amount of energy } \\
\text { in the next three months in my school. }\end{array}$ & 4.49 \\
\hline
\end{tabular}

A high subjective norm can positively influence the intention to save energy (see correlation and regression analyses). Unfortunately, the answers to the survey questions demonstrate that neither the classmates (4.20) nor the people who are important in the respondent's private life (4.42) believe that they should save energy in school.

Table 8. Mean for subjective norms (totally disagree (1) to completely agree (7)).

\begin{tabular}{cccc}
\hline Code & Question & Mean & Standard Deviation \\
\hline SN & $\begin{array}{c}\text { The influence of teachers, classmates, } \\
\text { and people in respondents' private lives on the } \\
\text { intention to save energy (a composite value) }\end{array}$ & 4.49 & 1.89 \\
\hline SN_1 & My teachers believe that I should save energy & 4.87 & 2.02 \\
in my school. & My classmates believe that I should save \\
energy in my school. & 4.20 & 2.38 \\
\hline SN_3 & $\begin{array}{c}\text { People who are important in my personal life } \\
\text { believe that I should save energy in my school. }\end{array}$ & 4.42 & 2.22 \\
\hline
\end{tabular}

Table 9 illustrates that the most important energy-saving motivation for students is to protect the environment (4.54), the second incentive is to save money (4.41), and the third is to feel satisfied (4.16). 
Table 9. Mean for energy-saving motivation (very unimportant (1) to very important (5)).

\begin{tabular}{cccc}
\hline Code & Question & Mean & Standard Deviation \\
\hline EM_1 & Energy-saving motivation: money & 4.41 & 0.92 \\
EM_2 & Energy-saving motivation: environment & 4.54 & 0.80 \\
EM_3 & Energy-saving motivation: hedonic & 4.16 & 0.98 \\
\hline
\end{tabular}

It can be stated that students do not have sufficient knowledge about energy consumption of different surrounding appliances. The respondents indicated that they know best how much energy the lights consume (3.45) and the least about how much energy is consumed by their laptop or computer (3.19).

Table 10. Mean for knowledge about energy saving (fully disagree (1) to fully agree (5)).

\begin{tabular}{|c|c|c|c|}
\hline Code & Question & Mean & Standard Deviation \\
\hline EN & $\begin{array}{l}\text { Knowledge about the energy consumption of the } \\
\text { surrounding electrical appliances (a composite value) }\end{array}$ & 3.54 & 1.15 \\
\hline EN_1 & $\begin{array}{l}\text { I know how much energy my laptop or } \\
\text { computer consumes. }\end{array}$ & 3.19 & 1.60 \\
\hline EN_2 & $\begin{array}{l}\text { I know how much energy the heating } \\
\text { system consumes. }\end{array}$ & 3.35 & 1.44 \\
\hline EN_3 & $\begin{array}{l}\text { I know how much energy the air } \\
\text { conditioning consumes. }\end{array}$ & 3.35 & 1.51 \\
\hline EN_4 & I know how much energy the lights consume. & 3.45 & 1.54 \\
\hline
\end{tabular}

In general, students were positioned between "Undecided" (3) and "Rather agree" (4) regarding their joint responsibility for energy problems, such as the exhaustion of energy sources or global warming (see Table 11).

Table 11. Mean for ascription of responsibility (fully disagree (1) to fully agree (5)).

\begin{tabular}{cccc}
\hline Code & \multicolumn{1}{c}{ Question } & Mean & Standard Deviation \\
\hline AR & $\begin{array}{c}\text { Joint responsibility for energy problems } \\
\text { (a composite value) }\end{array}$ & 3.72 & 0.96 \\
\hline AR_1 & I am jointly responsible for energy problems. & 3.80 & 1.26 \\
\hline AR_2 & $\begin{array}{c}\text { Not only the government and industry are } \\
\text { responsible for high energy consumption levels, } \\
\text { but me too. }\end{array}$ & 3.77 & 1.36 \\
\hline AR_3 & I feel jointly responsible for the exhaustion of \\
energy sources. & 3.93 & 1.20 \\
\hline AR_4 & I feel jointly responsible for global warming. & 3.84 & 1.61 \\
\hline AR_5 & $\begin{array}{c}\text { Although my school pays the bill, I feel that I } \\
\text { have to save as much energy as I can. }\end{array}$ & 3.27 & \\
\hline
\end{tabular}

Although the respondents believed that they are able to avoid unnecessary power consumption at school (4.64), they lack a feeling of control over the total amount of electricity consumed in their educational institution (3.30); see Table 12. 
Table 12. Mean for perceived behavioral control (not at all able to do it (1) to able to do it to a high extent (7)/very little control (1) to complete control (7)).

\begin{tabular}{cccc}
\hline Code & Question & Mean & Standard Deviation \\
\hline PBC & $\begin{array}{c}\text { Perceived behavioral control to limit power } \\
\text { consumption in school (a composite value) }\end{array}$ & 4.10 & 1.52 \\
\hline PBC_1 & $\begin{array}{c}\text { I believe that I am able to avoid unnecessary } \\
\text { power consumption at school. }\end{array}$ & 4.64 & 1.78 \\
\hline PBC_2 & $\begin{array}{c}\text { To what extent do you think you are able to } \\
\text { limit the power consumption at school to the } \\
\text { absolutely necessary levels? }\end{array}$ & 4.36 & 1.97 \\
\hline PBC_3 & $\begin{array}{l}\text { How much control do you personally feel you } \\
\text { have over the amount of electricity consumed } \\
\text { in school? }\end{array}$ & 3.30 & \\
\hline
\end{tabular}

To sum up, the results of the descriptive statistics analysis show that the most important energy-saving motivation for students is to protect the environment (4.54). Nevertheless, the students neither feel very morally obliged to save energy (4.40/7) nor have a strong behavioral intention to save energy in their school (4.49/7). In addition to this, the respondents do not have sufficient knowledge about the energy consumption of the surrounding electrical appliances (3.33/7). Moreover, they lack a feeling of control over the total amount of electricity consumed in their educational institution (3.30/7). Finally, and unfortunately, the answers to the survey questions demonstrate that neither the classmates (4.20/7), nor the teachers (4.87/7), nor other people who are important in the respondent's private life $(4.42 / 7)$ believe that they should save energy in their school.

\subsection{Correlation Analysis}

All those correlations which were significant at a 5\% level are presented in Tables 13-15; however, only those with a significance of $1 \%$ are discussed below.

It can be noted that all sociodemographic features (gender, age, education level, study field) are important when we analyze the determinants of energy-saving behavior. Table 13 illustrates that female students are more likely than males to feel responsible for energy problems, such as the exhaustion of energy sources or global warming. Gender, together with education level, also plays a significant role in the level of moral obligation to consider the environment and save energy, and in having a greater motivation to save a substantial amount of energy in the vocational school during the upcoming three months.

Table 13. Correlation analysis (1).

\begin{tabular}{clcccccc}
\hline & & AR & PBC & PN & BI & EN & SN \\
\hline \multirow{2}{*}{ Gender } & Correlation Coef. & $0.268^{* *}$ & 0.15 & $0.272^{* *}$ & $0.264^{* *}$ & -0.033 & 0.143 \\
& Sig. (two-tailed) & 0.005 & 0.118 & 0.004 & 0.005 & 0.737 & 0.136 \\
\hline \multirow{2}{*}{ Age } & Correlation Coef. & 0.134 & 0.147 & $0.225^{*}$ & 0.072 & $0.200^{*}$ & $0.194^{*}$ \\
& Sig. (two-tailed) & 0.163 & 0.126 & 0.018 & 0.456 & 0.037 & 0.042 \\
\hline \multirow{2}{*}{ Education } & Correlation Coef. & 0.142 & $0.239^{*}$ & $0.312^{* *}$ & $0.272^{* *}$ & 0.13 & -0.11 \\
level & Sig. (two-tailed) & 0.14 & 0.012 & 0.001 & 0.004 & 0.177 & 0.252 \\
\hline \multirow{2}{*}{ Study field } & Correlation Coef. & $0.225^{*}$ & $0.278^{* *}$ & 0.132 & $0.215^{*}$ & 0.124 & $0.218^{*}$ \\
& Sig. (two-tailed) & 0.024 & 0.005 & 0.171 & 0.041 & 0.2 & 0.028 \\
\hline
\end{tabular}

${ }^{*}$ Correlation is significant at the 0.05 level (two-tailed), ${ }^{* *}$ Correlation is significant at the 0.01 level (two-tailed). Correlation Coef. Sig., Correlation Coefficient's Significance; AR, ascription of responsibility; PBC, perceived behavioral control; PN, personal norms; BI, behavioral intention; EN, knowledge about energy saving; $\mathrm{SN}$, subjective norm. 
Demographic factors can also determine the incentive to save energy. Female students, for example, tend to reduce their energy consumption in order to save money. If students are compared by age group, it is worth mentioning that older age groups care about the environment more than younger ones.

Table 14. Correlation analysis (2).

\begin{tabular}{ccccc}
\hline \multirow{2}{*}{ Gender } & & EM_1 & EM_2 & EM_3 \\
& Correlation Coef. & $0.300^{* *}$ & $0.204^{*}$ & $0.191^{*}$ \\
& Sig. (two-tailed) & 0.001 & 0.032 & 0.046 \\
\hline \multirow{2}{*}{ Age } & Correlation Coef. & $0.234^{*}$ & $0.270^{* *}$ & 0.035 \\
& Sig. (two-tailed) & 0.014 & 0.004 & 0.718 \\
\hline \multirow{2}{*}{ Education level } & Correlation Coef. & 0.131 & 0.174 & 0.12 \\
& Sig. (two-tailed) & 0.173 & 0.069 & 0.213 \\
\hline \multirow{2}{*}{ Study field } & Correlation Coef. & $0.243^{*}$ & $0.211^{*}$ & $0.329^{*}$ \\
& Sig. (two-tailed) & 0.029 & 0.041 & 0.017 \\
\hline
\end{tabular}

* Correlation is significant at the 0.05 level (two-tailed), ${ }^{* *}$ Correlation is significant at the 0.01 level (two-tailed). Correlation Coef. Sig., Correlation Coefficient's Significance; EM_1, energy-saving motivation: money; EM_2, energy-saving motivation: environment; EM_3, energy-saving motivation: hedonic.

The correlation analysis presented below was devoted to checking the interrelations between the social and psychological determinants. The strongest relationship (0.585) at the 0.01 significance level was found between the personal norms and the behavioral intention. Due to this fact, it was decided to perform a regression analysis that showed the exact predictors of the variable "Behavioral intention to save energy in the next three months in my school"; see Section 4.2.

The analysis also suggests that if a student feels jointly responsible for high energy consumption levels, they will also feel that they have more control over the amount of electricity consumed in the school (AR/PBC 0.404, $p<0,01)$.

Furthermore, it is proved that the influence of other people is very important in the energy-saving processes (SN/PN 0.378, $p<0.01$; SN/BI 0.398, $p<0.01$; SN/AR 0.296, $p<0,01$; SN/PBC 0.280, $p<0.01$ ).

There was no significant relationship found between the knowledge about energy saving and other sociopsychological determinants.

Table 15. Correlation analysis (3).

\begin{tabular}{|c|c|c|c|c|c|c|c|}
\hline & & $\mathbf{P N}$ & BI & SN & EN & AR & PBC \\
\hline \multirow{2}{*}{$\mathrm{PN}$} & Correlation Coef. & 1 & $0.585^{* *}$ & $0.378^{* *}$ & 0.013 & $0.420 * *$ & $0.312^{* *}$ \\
\hline & Sig. (two-tailed) & - & 0 & 0 & 0.893 & 0 & 0.001 \\
\hline \multirow{2}{*}{ BI } & Correlation Coef. & $0.585^{* *}$ & 1 & $0.398 * *$ & 0.07 & $0.406^{* *}$ & 0.386 ** \\
\hline & Sig. (two-tailed) & 0 & - & 0 & 0.468 & 0 & 0 \\
\hline \multirow{2}{*}{$\mathrm{SN}$} & Correlation Coef. & $0.378^{* *}$ & $0.398^{* *}$ & 1 & 0.064 & $0.296^{* *}$ & $0.280 * *$ \\
\hline & Sig. (two-tailed) & 0 & 0 & - & 0.507 & 0.002 & 0.003 \\
\hline \multirow{2}{*}{$\mathrm{EN}$} & Correlation Coef. & 0.013 & 0.07 & 0.064 & 1 & -0.022 & 0.174 \\
\hline & Sig. (two-tailed) & 0.893 & 0.468 & 0.507 & - & 0.821 & 0.07 \\
\hline \multirow{2}{*}{$\mathrm{AR}$} & Correlation Coef. & $0.420 * *$ & $0.406^{* *}$ & $0.296^{* *}$ & -0.022 & 1 & $0.404^{* *}$ \\
\hline & Sig. (two-tailed) & 0 & 0 & 0.002 & 0.821 & - & 0 \\
\hline \multirow{2}{*}{ PBC } & Correlation Coef. & $0.312 * *$ & 0.386 ** & $0.280 * *$ & 0.174 & $0.404^{* *}$ & 1 \\
\hline & Sig. (two-tailed) & 0.001 & 0 & 0.003 & 0.07 & 0 & - \\
\hline
\end{tabular}

* Correlation is significant at the 0.05 level (two-tailed), ${ }^{* *}$ Correlation is significant at the 0.01 level (two-tailed). Correlation Coef. Sig., Correlation Coefficient's Significance; AR, ascription of responsibility; PBC, perceived behavioral control; PN, personal norms; BI, behavioral intention; EN, knowledge about energy saving; SN, subjective norm.

Summarizing, it can be remarked that low subjective norms and low perceived behavioral control are not likely to form a strong behavioral intention to save energy. In addition to this, it can be 
emphasized that of all the sociodemographic features that have a significant relationship with social and psychological determinants of energy saving, gender is the most important. The analysis revealed that female students feel more responsible for energy problems, such as the exhaustion of energy sources or global warming, than males. Gender, together with education level, also plays a significant role in the level of moral obligation to consider the environment and save energy, and in having a greater motivation to save a substantial amount of energy in school.

\subsection{Regression Analysis}

The stepwise linear regression method of regressing multiple variables while simultaneously removing those that are not important was used in the regression analysis.

The tables below (see Tables 16 and 17) present the key statistics of the final version of a multiple linear regression model (with omitted insignificant variables). It can be noted that the predictors "Personal norms towards the reduction of energy use", "Behavioral control to limit the power consumption" and "Influence of teachers, classmates, and other important people in life on the intention to save energy" can explain the fluctuations of the dependent variable "Behavioral intention to save a substantial amount of energy in the next three months in school" by $39 \%$.

Table 16. Model summary.

\begin{tabular}{cccc}
\hline $\boldsymbol{R}$ & $\boldsymbol{R}$-Square & Adjusted $\boldsymbol{R}$-Square & Standard Error of the Estimate \\
\hline 0.638 & 0.407 & 0.390 & 1.028 \\
\hline
\end{tabular}

Table 17. Final results of the statistical significance test.

\begin{tabular}{|c|c|c|c|c|c|c|c|}
\hline & \multicolumn{2}{|c|}{ Unstandardized Coefficients } & \multirow{2}{*}{$\frac{\text { Standardized Coefficients }}{\text { Beta }}$} & \multirow{2}{*}{$t$} & \multirow{2}{*}{ Sig. } & \multicolumn{2}{|r|}{ Collinearity Statistics } \\
\hline & $B$ & Standard Error & & & & Tolerance & Variance Inflation Factor (VIF) \\
\hline (Constant) & 0.051 & 0.540 & - & 0.094 & 0.925 & - & - \\
\hline $\mathrm{PN}$ & 0.690 & 0.127 & 0.455 & 5.415 & 0.000 & 0.801 & 1.249 \\
\hline PBC & 0.167 & 0.069 & 0.192 & 2.406 & 0.018 & 0.891 & 1.123 \\
\hline $\mathrm{SN}$ & 0.124 & 0.058 & 0.178 & 2.156 & 0.033 & 0.829 & 1.206 \\
\hline
\end{tabular}

Dependent Variable: BI, behavioral intention. PN, personal norms; PBC, perceived behavioral control; SN, subjective norm.

There is no multicollinearity (see Table 17$)$ between the independent variables $(1 \leq \mathrm{VIF} \leq 10)$, thus the final proposed regression model equation is as follows:

$$
Y_{B I}=0.69_{P N}+0.167_{P B C}+0.124_{S N}
$$

Accordingly, it can be concluded that an intention to save a substantial amount of energy in school is greater when pupils (i) feel morally obliged to consider the environment and nature while saving energy in their daily behavior; (ii) believe that it is in their power to avoid unnecessary power consumption at school; and (iii) are positively influenced by teachers, classmates, and other important people in their lives.

\section{Conclusions}

The scientific analysis shows that the behavior regarding energy efficiency in schools should be analyzed and evaluated by distinguishing determinants and reflecting the characteristics of consumer behavior.

Psychological and social determinants, sociodemographic and economic determinants, and contextual determinants can affect and be important in the behavior of occupants in schools, which finally has an impact on the efficient use of energy. 
According to the review of research papers, the most frequently studied determinants of energy use in schools in terms of their influence on sustainable energy consumption are as follows:

(1) attitudes;

(2) incentives, intentions, motivation;

(3) knowledge; and

(4) awareness.

The results of the survey revealed that the most important energy-saving motivation for students in a vocational school in Greece is to protect the environment. Furthermore, an intention to save a substantial amount of energy in school is greater when pupils feel morally obliged to consider the environment and nature, believe that it is in their power to avoid unnecessary power consumption at school, and are positively influenced by teachers, classmates, and other important people in their lives. It is also worth noting that female students tend to feel more responsible for energy problems than males and have a greater motivation to save energy in their school.

These results may be applied to the consideration of interventions for students in schools to encourage energy-saving behavior. Further research on interventions applied in schools would provide a practical contribution to efficient energy use.

The studies including a higher number of schools or even schools in different countries would provide more reliable results.

This paper contributes to research in the area of sustainable energy consumption in schools and occupants' behavior in energy efficiency.

Author Contributions: Conceptualization: D.D. and A.C.; Methodology: D.D., A.C. and M.A.; Software: M.A.; Validation: D.D., A.C. and M.A.; Investigation: D.D., A.C. and M.A.; Supervision: D.D.; Writing and Review: D.D., A.C. and M.A.

Funding: This work was partially supported by the "enCOMPASS-Collaborative Recommendations and Adaptive Control for Personalized Energy Saving" project funded by the EU H2020 Programme, grant agreement no. 723059 .

Conflicts of Interest: The authors declare no conflict of interest. The funders had no role in the design of the study; in the collection, analyses, or interpretation of data; in the writing of the manuscript; or in the decision to publish the results.

\section{References}

1. Mtutu, P.; Thondhlana, G. Encouraging pro-environmental behavior: Energy use and recycling at Rhodes University, South Africa. Habitat Int. 2016, 53, 142-150. [CrossRef]

2. Altan, H. Energy efficiency interventions in UK higher education institutions. Energy Policy 2010, 38, 7722-7731. [CrossRef]

3. Amutenya, N.; Shackleton, C.M.; Whittington-Jones, K. Paper recycling patterns and potential interventions in the education sector: A case study of paper streams at Rhodes University, South Africa. Resour. Conserv. Recycl. 2009, 53, 237-242. [CrossRef]

4. Marcell, K.; Agyeman, J.; Rappaport, A. Cooling the campus: Experiences from a pilot study to reduce electricity use at Tufts University, USA, using social marketing methods. Int. J. Sustain. High. Educ. 2004, 5, 169-189. [CrossRef]

5. Pisello, A.L.; Castaldo, V.L.; Piselli, C.; Fabiani, C.; Cotana, F. How peers' personal attitudes affect indoor microclimate and energy need in an institutional building: Results from a continuous monitoring campaign in summer and winter conditions. Energy Build. 2016, 126, 485-497. [CrossRef]

6. Manika, D.; Gregory-Smith, D.; Wells, V.; Graham, S. Home vs. Workplace Energy Saving Attitudes and Behaviors: The Moderating Role of Satisfaction with Current Environmental Behaviors, Gender, Age, and Job Duration. In Proceedings of the AMA Winter Marketing Educators' Conference 2015: Marketing in a Global, Digital and Connected World, San Antonio, TX, USA, 13-15 February 2015. 
7. European Environment Agency. Final Energy Consumption by Sector. European Environment Agency, Luxembourg. Available online: https://www.eea.europa.eu/data-and-maps/indicators/final-energyconsumption-by-sector-5/assessment (accessed on 27 October 2017).

8. Salleh, M.N.M.; Kandar, M.Z.; Sakip, S.R.M. Benchmarking for Energy Efficiency on School Buildings Design: A Review. Procedia-Soc. Behav. Sci. 2016, 222, 211-218. [CrossRef]

9. Zografakis, N.; Menegaki, A.N.; Tsagarakis, K.P. Effective education for energy efficiency. Energy Policy 2008, 36, 3226-3232. [CrossRef]

10. Schelly, C.; Cross, J.E.; Franzen, W.S.; Hall, P.; Reeve, S. Reducing Energy Consumption and Creating a Conservation Culture in Organizations: A Case Study of One Public School District. Environ. Behav. 2010, 43, 316-343. [CrossRef]

11. Craig, C.A.; Allen, M.W. The impact of curriculum-based learning on environmental literacy and energy consumption with implications for policy. Util. Policy 2015, 35, 41-49. [CrossRef]

12. Kastner, I.; Matthies, E. Implementing web-based interventions to promote energy efficient behavior at organizations-A multi-level challenge. J. Clean. Prod. 2014, 62, 89-97. [CrossRef]

13. DeWaters, J.E.; Powers, S.E. Energy literacy of secondary students in New York State (USA): A measure of knowledge, affect, and behavior. Energy Policy 2011, 39, 1699-1710. [CrossRef]

14. Castleberry, B.; Gliedt, T.; Greene, J.S. Assessing drivers and barriers of energy-saving measures in Oklahoma's public schools. Energy Policy 2016, 88, 216-228. [CrossRef]

15. Murtagh, N.; Nati, M.; Headley, W.R.; Gatersleben, B.; Gluhak, A.; Imran, M.A.; Uzzell, D. Individual energy use and feedback in an office setting: A field trial. Energy Policy 2013, 62, 717-728. [CrossRef]

16. Kemp-Hesterman, A.; Glick, S.; Eileen Cross, J. Reducing electrical energy consumption through behavior changes. J. Facil. Manag. 2014, 12, 4-17. [CrossRef]

17. Moher, D.; Larissa, S.; Mike, C.; Davina, G.; Alessandro, L.; Mark, P.; Paul, S.; Lesley, A.S. Preferred reporting items for systematic review and meta-analysis protocols (PRISMA-P) 2015 statement. Syst. Rev. 2015, 4, 1. [CrossRef] [PubMed]

18. Armstrong, R.; Hall, B.J.; Doyle, J.; Waters, E. Scoping the scope'of a cochrane review. J. Public Health 2011, 33, 147-150. [CrossRef] [PubMed]

19. Dewey, A.; Drahota, A. Introduction to Systematic Reviews: Online Learning Module Cochrane Training. Available online: https://raining.cochrane.org/interactivelearning/module-1-introduction-conductingsystematic-reviews (accessed on 15 January 2017).

20. Dumciuviene, D.; Cibinskiene, A.; Melenhorst, M.; Novak, J. Determinants of Sustainable Energy Consumption in Schools. Proceedings 2018, 2, 1382. [CrossRef]

21. Frederiks, E.R.; Stenner, K.; Hobman, E.V. Household energy use: Applying behavioral economics to understand consumer decision-making and behavior. Renew. Sustain. Energy Rev. 2015, 41, 1385-1394. [CrossRef]

22. Scherbaum, C.A.; Popovich, P.M.; Finlinson, S. Exploring Individual-Level Factors Related to Employee Energy-Conservation Behaviors at Work. J. Appl. Soc. Psychol. 2008, 38, 818-835. [CrossRef]

23. Whittle, R.; Ellis, R.; Marshall, I.; Alcock, P.; Hutchison, D.; Mauthe, A. From responsibility to accountability: Working creatively with distributed agency in office energy metering and management. Energy Res. Soc. Sci. 2015, 10, 240-249. [CrossRef]

24. Schwartz, S.H. Normative influences on altruism. In Advances in Experimental Social Psychology; Academic Press: New York, NY, USA, 1977; pp. 221-279. [CrossRef]

25. Steg, L.; Dreijerink, L.; Abrahamse, W. Factors influencing the acceptability of energy policies: a test of VBN theory. J. Personal. Soc. Psychol. 2005, 25, 415-425. [CrossRef]

26. Thøgersen, J.; Grønhøj, A. Electricity saving in households-A social cognitive approach. Energy Policy 2010, 38, 7732-7743. [CrossRef]

27. Ajzen, I. The theory of planned behavior. Organ. Behav. Hum. Decis. Process. 1991, 50, 179-211. [CrossRef]

28. Lo, S.H.; Peters, G.-J.Y.; Kok, G. A review of determinants of and interventions for proenvironmental behaviors in organizations. J. Personal. Soc. Psychol. 2012, 42, 2933-2967. [CrossRef]

29. Azar, E.; Al Ansari, H. Framework to investigate energy conservation motivation and actions of building occupants: The case of a green campus in Abu Dhabi, UAE. Appl. Energy 2017, 190, 563-573. [CrossRef]

30. Dixon, G.N.; Deline, M.B.; McComas, K.; Chambliss, L.; Hoffmann, M. Saving energy at the workplace: the salience of behavioral antecedents and sense of community. Energy Res. Soc. Sci. 2015, 6, 121-127. [CrossRef] 
31. Dixon, G.N.; Deline, M.B.; McComas, K.; Chambliss, L.; Hoffmann, M. Using Comparative Feedback to Influence Workplace Energy Conservation: A Case Study of a University Campaign. Environ. Behav. 2015, 47, 667-693. [CrossRef]

32. Al-Shemmeri, T.; Naylor, L. Energy saving in UK FE colleges: The relative importance of the socio-economic groups and environmental attitudes of employees. Renew. Sustain. Energy Rev. 2017, 68, 1130-1143. [CrossRef]

33. Staats, H.; van Leeuwen, E.; Wit, A. A longitudinal study of informational interventions to save energy in an office building. J. Appl. Behav. Anal. 2000, 33, 101-104. [CrossRef]

34. Cotton, D.; Shiel, C.; Paço, A. Energy saving on campus: a comparison of students' attitudes and reported behaviors in the UK and Portugal. J. Clean. Prod. 2016, 129, 586-595. [CrossRef]

35. Axaopoulos, P.; Pitsilis, G. Energy software programs for educational use. Renew. Energy 2007, 32, $1045-1058$. [CrossRef]

36. Ishak, M.H.; Iman, A.H.M.; Sapri, M. Theoretical postulation of energy consumption behavior assessment in Malaysian higher education institutions. Procedia-Soc. Behav. Sci. 2012, 65, 891-896. [CrossRef]

37. Kamilaris, A.; Neovino, J.; Kondepudi, S.; Kalluri, B. A case study on the individual energy use of personal computers in an office setting and assessment of various feedback types toward energy savings. Energy Build. 2015, 104, 73-86. [CrossRef]

38. Kalpana, K.; Rajkumar, A.D.; Rita, S. A study on "Students awareness, attitude and behavior towards energy conservation". Int. J. Appl. Bus. Econ. Res. 2013, 2, 241-250.

39. Desrochers, M.N.; Mosher, H. Evaluation of an informational and behavior change program to increase students' self-reported energy conservation. Behav. Interv. 2017, 32, 225-233. [CrossRef]

40. Sahin, E. Predictors of Turkish Elementary Teacher Candidates' Energy Conservation Behaviors: An Approach on Value-Belief-Norm Theory. Int. J. Environ. Sci. Educ. 2013, 8, 269-283. [CrossRef]

41. Matthies, E.; Kastner, I.; Klesse, A.; Wagner, H.J. High reduction potentials for energy user behavior in public buildings: how much can psychology-based interventions achieve? J. Environ. Stud. Sci. 2011, 1, 241. [CrossRef]

42. Börner, D.; Kalz, M.; Specht, M. It doesn't matter, but: examining the impact of ambient learning displays on energy consumption and conservation at the workplace. Environ. Educ. Res. 2015, 21, 899-915. [CrossRef]

43. Lourenço, P.; Pinheiro, M.D.; Heitor, T. From indicators to strategies: Key Performance Strategies for sustainable energy use in Portuguese school buildings. Energy Build. 2014, 85, 212-224. [CrossRef]

44. Tornelli, P.J. Case Study: Successful Low Cost Energy Efficiency And Cost Control Strategies for a Rapidly Growing School District. Strateg. Plan. Energy Environ. 2008, 28, 53-74. [CrossRef]

45. Serghides, D.K.; Chatzinikola, C.K.; Katafygiotou, M.C. Comparative studies of the occupants' behavior in a university building during winter and summer time. Int. J. Sustain. Energy 2015, 34, 528-551. [CrossRef] 